\title{
HÁLÓZATI STRUKTÚRA ÉS CENTRALITÁS A DIPLOMÁCIAI HÁLÓZATOKBAN
}

\section{NETWORK STRUCTURE AND CENTRALITY AND DIPLOMATIC NETWORKS}

\author{
Kacziba Péter \\ PhD, egyetemi adjunktus, Pécsi Tudományegyetem Bölcsészettudományi Kar Politikatudományi és Nemzetközi Tanulmányok Tanszék \\ kacziba.peter@pte.hu
}

\section{ÖSSZEFOGLALÁS}

Jelen tanulmány célja, hogy multidiszciplináris megközelítéssel vizsgálja az 1817-2015 közötti diplomáciai hálózatok strukturális jellegzetességeit, egyúttal elemezze, hogy a kapcsolatszerkezetben mely államok töltöttek be központi pozíciót. A vizsgálat során negyven hálózati modell elemzéséből következő részeredmények kerülnek bemutatásra: a tanulmány felvázolja a csúcspontokkal, élekkel és azok történeti változásaival kapcsolatos jellemzőket; áttekinti a sűrűséggel és reciprocitással kapcsolatos adatokat; illetve a fokszámcentralitásból kinyert információk alapján megkísérli detektálni a hálózatokban központi szerepet játszó aktorokat.

\section{ABSTRACT}

This study seeks to analyze the structural characteristics of diplomatic networks between 1817 and 2015 with a multidisciplinary approach and attempt to examine which states have occupied a central position in the network structures. The paper presents partial results of the analysis of forty diplomatic network models: it outlines the topological characteristics of nodes, edges, and their historical transformations; reviews data on density and reciprocity; and on the basis of information obtained from degree centricity, it attempts to detect central actors of the network structures.

Kulcsszavak: nemzetközi kapcsolatok, diplomácia, hálózatkutatás, digitális bölcsészet

Keywords: international relations, diplomacy, network research, digital humanities

\section{BEVEZETÉS}

Az előző évtizedekben a globális tér és az abban lezajló interakciók fokozódó komplexitása kihívás elé állította a nemzetközi kapcsolatokkal foglalkozó kutatásokat. Az állami és nem állami szereplők számának drasztikus növekedé- 
se, valamint a technikai innovációk és a globalizáció következményei új módszertani alternatívák kidolgozását és átvételét követelték meg. Ezek közül az egyik legígéretesebb lehetőséget a hálózattudomány alkalmazása biztosította, amely fogékony - ennek ellenére periferikus - módszertani alternatívának bizonyult a nemzetközi kapcsolatok fejlődésének lekövetésében. Ugyan a hálózati megközelítés diszciplináris alkalmazása korántsem tekinthető új jelenségnek, a kapcsolatszerkezeti modellezés és elemzés az informatikai, illetve digitális technikák széles körű elterjedéséig ezen a tudományterületen periferikus módszertani alternatíva maradt. A nemzetközi tanulmányokban alkalmazott hálózati módszertan az 1960-as évek óta kiemelt figyelmet szentel a rendszerszintü, globális összefüggések jellemzőivel foglalkozó kutatásoknak. Ezek a strukturális elemzések részletesen vizsgálták az államközpontú nemzetközi rendszer sajátosságait; a kereskedelmi folyamatok hálózati összefüggéseit; a nemzetközi interakciók, tranzakciók és kohéziók tulajdonságait; a szervezeti tagságok következményeit; a regionális klaszterezettséget vagy a szövetségi rendszerek alapvetéseit (Victor et al., 2017, 11.). Utóbbiak mellett a rendszerszintủ megközelítések egyik leghangsúlyosabb vonulata az államok közötti diplomáciai kapcsolatokra fókuszált, a diplomáciai linkek meglétéből, hiányából és jellegéből próbált a nemzetközi rendszerre, a centrális vagy periferikus, illetve a regionális vagy individuális szereplőkre vonatkozó tulajdonságokat kinyerni (például: Russet-Lamb, 1969; Neumayer, 2008, Westerwinter, 2017).

Jelen tanulmány ezt a kutatási trendet követve a globális diplomáciai hálózatok általános szerkezeti tulajdonságainak bemutatására, illetve a kapcsolatszerkezetek centrális szereplőinek detektálására vállalkozik. Bár a kutatási eredmények sokrétűek, ehelyütt terjedelmi korlátok miatt az általános szerkezeti tulajdonságok esetében a csúcspontok és kapcsolati linkek összetételére és változásaira, a sürüségi és reciprocitási adatokra, illetve a fokszámeloszlására fókuszálok; a centralitásra vonatkozó attribútumokat pedig csak a fokszámközpontiság mérőszámai alapján elemzem. Az írásban röviden összefoglalt kutatási eredmények újdonságát elsősorban a mintavételi eljárás széles idősávja biztosítja: míg a korábbi elemzések rövid periódusokra vonatkozóan vizsgálták a diplomáciai hálózatok jellegzetességeit, addig jelen kutatás és tanulmány relatíve széles időskálára, az 1817-2015 közötti időszakra helyezi a hangsúlyt.

A tanulmányban található ábrák saját szerkesztés eredményei, amelyek a modellezett hálózatokból kinyert adatok alapján kerültek összeállításra. Helytakarékossági okokból ezen adatok és hálózatok forrásait külön-külön nem tüntettem fel, ehelyütt azonban szükséges jelezni, hogy az összeállított hálózatok és az abból kinyert adatok forrásai: Bayer, 2006; Moyer et al., 2016; Europa Publications, 2016. 


\section{MÓDSZERTAN}

A tanulmány kiindulópontjául szolgáló kutatás kifejezetten a diplomáciai kapcsolódások felépítésének és változásainak hosszú idősoros leírására vállalkozott, emiatt azonban számos módszertani kihívással találta szemben magát. Ezek közül az első nagyobb problémát az adatfelvétel jelentette, egységes adatbázis hiányában ugyanis az elemzett periódus diplomáciai kapcsolatait csak három, eltérő módszertant alkalmazó forrásból lehetett kinyerni. Ennek megfelelően az 1817 és 1960 közötti hálózatok forrása a Correlates of War projekt legfrissebb, Reşat Bayer által jegyzett adatbázisa (v2006.1.); az 1960-2010 közötti adatok Jonathan D. Moyer és munkatársai Diplometrics elnevezésủ adatgyüjtéséből származnak; míg az utóbbiak által még nem tárgyalt 2015-ös év a The Europa World Year Book diplomáciai információinak eredménye (Bayer, 2006; Moyer et al., 2016; Europa Publications, 2016).

Az adatbázisok jellegéből adódóan a modellezett és vizsgált hálózatok az államok közötti diplomáciai kapcsolatokat ábrázolták, a nemzetközi szervezetekhez küldött állandó képviseletek tehát nem képezték a kutatás tárgyát. Szintén az adatforrások eltérő módszertani sajátosságaiból következően a hálózatokban 1960 előtt diplomáciai akkreditáció eredményezett hálózati kapcsolatot, azt követően viszont már rezidens képviselet jelenléte. Mivel a használt adatbázisok képviseleti osztályozása is eltér egymástól, ezért a kutatás külképviseleti missziók eltérő formáit és szintjeit nem osztályozta vagy kategorizálta: a hálózatok az adott mintavételi évben jelen lévő kapcsolatokat nagyköveti, föképviselői ${ }^{1}$, ügyvivői, miniszteri, esetleg egyéb képviselöi ${ }^{2}$ szinten ábrázolták, ezek között azonban nem tettek különbséget. Az 1960-at megelőző, akkreditációs adatgyüjtés folyományaként a rezidens képviseletek esetén is minden esetben csak maximum egy diplomáciai képviselet került ábrázolásra, tehát az adott országba delegált vezető képviseleten kívül létesített alsóbbrendủ missziók külön nem kerültek feltüntetésre.

A kutatás jobbára ötéves mintavételi időszakokban vizsgálta a külképviseleti kapcsolatokat, bizonyos években (például a második világháború alatt és után) a felhasznált adatbázisok ugyanakkor nem szolgáltattak adatokat. ${ }^{3}$ Az elemzésben az adatbázisok által kiválasztott állami entitások szerepelnek, azonban a Correlates of War adatgyüjtési eljárásának megfelelően a Diplometrics gyűjtéséből is ki lettek szürve az önálló szuverenitással nem vagy csak korlátozottan rendelkező államok. Ez például a 2015-ös évet alapul véve azt jelenti, hogy a 193 ENSZ

${ }^{1}$ A Brit Nemzetközösség egymáshoz delegált, nagyköveti rangú képviselői, angolul: High Commisioner.

${ }^{2}$ Például apostoli nuncius.

${ }^{3}$ A konkrét mintavételi évek a következök: 1817, 1824, 1827, 1832, 1836, 1840, 1844, 1849, 1854, 1859, 1864, 1869, 1874, 1879, 1884, 1889, 1894, 1899, 1904, 1909, 1914, 1920, 1925, 1930, 1935, 1940, 1950, 1955, 1960, 1965, 1970, 1975, 1980, 1985, 1990, 1995, 2000, 2005, 2010, 2015. 
tagsággal rendelkező országon kívül csak olyan államok kerültek be a hálózatba, amelyek ténylegesen és széles körben tudták gyakorolni szuverenitásukat. ${ }^{4}$ Szintén fontos leszögezni, hogy a hálózatok izolált részeket nem tartalmaznak, azaz csak azok az országok kerültek bele a hálózatokba, amelyek az adott mintavételi évben legalább egy másik országgal a kritériumoknak megfelelő diplomáciai kapcsolatban álltak.

A kapcsolatok vizuális modellezését a Gephi 0.9.2 verziószámú szoftver végezte el (Bastian et al., 2009). A modellezett hálózatokban az államok (csúcspontok) közötti diplomáciai interakciókat a bejövő és kimenő képviseletek irányított linkjei jelzik, minden egyes diadikus pár egymáshoz maximum két éllel kapcsolódhat, egy bejövő és egy kimenő misszióval (lásd: melléklet). Utóbbiból következően az összeállított kapcsolati szerkezetek irányított hálózatok. Végezetül fontos kiemelni, hogy az adatbázisok saját bevallásuk szerint is tartalmazhatnak anomáliákat, ekkora adatmennyiség esetében a hibalehetőség tehát nem elhanyagolható tényező (Moyer et al., 2016, 7.).

\section{HÁLÓZATI STRUKTÚRA}

Az elemzés tárgyát képező negyven hálózat összevetésekor az egyik legszembetűnőbb jellegzetesség a szerkezeti komplexitás folyamatos és fokozatos növekedése, amely bizonyos években kisebb-nagyobb mértékben fluktuált ugyan, a mintavételi időszak egészére nézve azonban jellemző. Ez a komplexitás-növekedés következik egyrészt a hálózatban részt vevő államok számának emelkedéséből, másrészt a közöttük lévő interakciók arányának fokozódásából. A kutatás által modellezett diplomáciai hálózatokban részt vevő államok/csúcspontok $(N)$ száma 1817-1914 között 91,3\%-kal emelkedett, amit jóval meghaladott az 1914 és 2015 közötti 345,5\%-os növekedés (1. ábra). Ebben a vonatkozásban a német egyesítés alatti és utáni, valamint a második világháború alatti időszak annexiói jelentettek számottevő kivételt, mindkét esetben átmeneti visszaesés mutatkozott a hálózatokban részt vevő államok számában.

A hálózati komplexitás növekedésének másik mozgatórugója az interakciók számának emelkedése volt. Az ezeket reprezentáló hálózati élek (L) száma 18171914 között 365,7\%-kal, 1914-2015 között pedig 895,2\%-kal növekedett (2. ábra). Bár ezek a számok kétségkívül jelentős növekedésről tanúskodnak, fontos azonban megjegyezni, hogy a hálózatokban részt vevő államok maximális kapcsolódási lehetőségeiknek ( $\left.L_{\max }\right)$ csak átlagosan 33,3\%-át használták fel (3. ábra).

\footnotetext{
${ }^{4}$ Névlegesen: Tajvan, a Szentszék és Koszovó. A kutatási következetesség miatt nem került az elemzett országok közé Palesztina és Észak-Ciprus sem, mivel ezekben az esetekben a szuverenitás tényleges gyakorlása erősen korlátozott.
} 


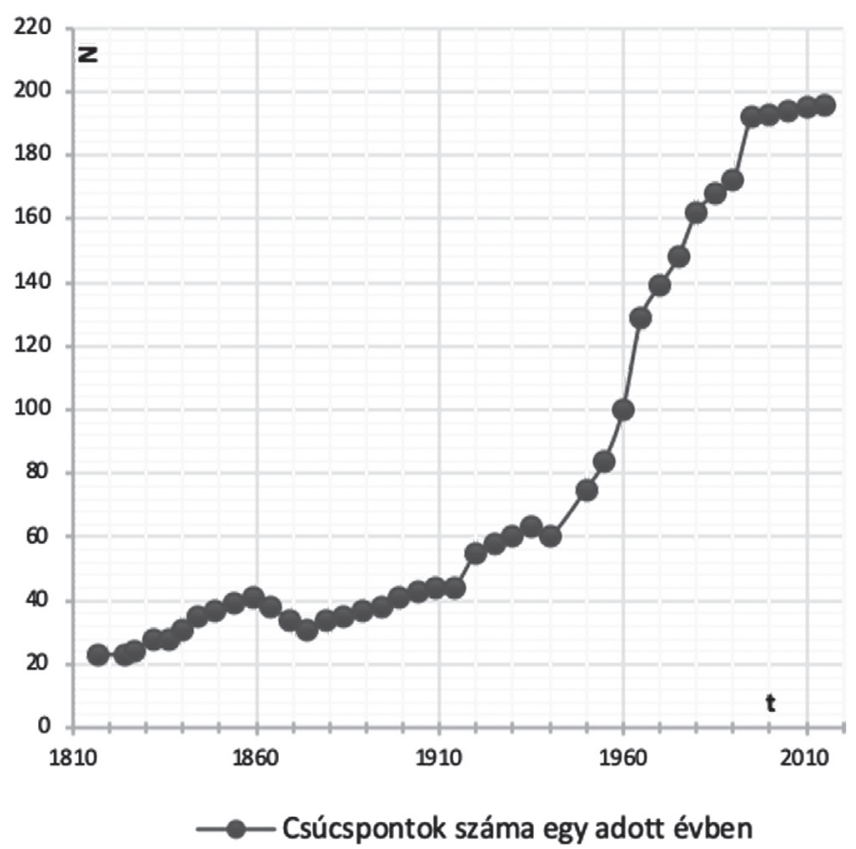

1. ábra. Államok/csúcspontok száma (1817-2015)

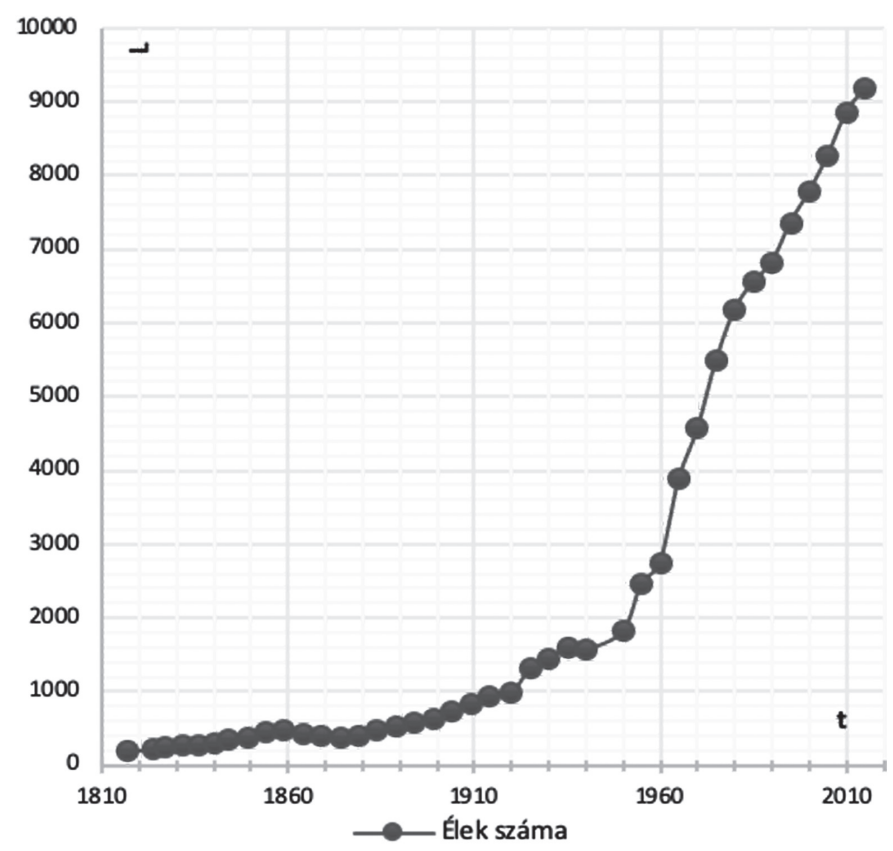

2. ábra. Hálózati kapcsolatok/élek száma (1817-2015) 


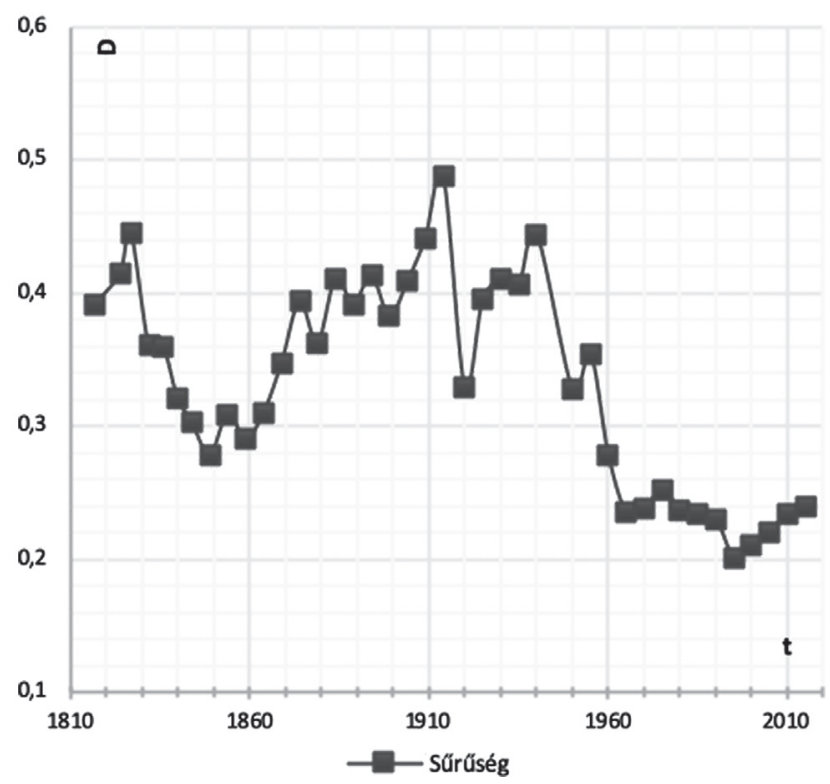

3. ábra. Hálózati sűrüség (1817-2015)

A hálózati sürűség $(D)$ értéke az elemzett évek során egyetlenegyszer sem haladta meg a $D=0,5-$ öt $^{5}$, az arány pedig látványosan csökkent a hálózatok méretének növekedésével. Míg a hálózatokban részt vevő államok 1817-1955 között átlag 37,6\%-át teljesítették maximális kapcsolódási lehetőségeiknek, addig 1960 és 2015 között - $L_{\max } 286,06 \%$ növekedése mellett - csak 23,4\%-át. A sürüség látványos csökkenésének egyik oka az államok számának folyamatos emelkedése, amely a maximális kapcsolódási lehetöségek arányát megnövelte. Ez a növekedés az államok közötti interakciók számát fokozta, komplexebb hálózatokat hozott létre, ugyanakkor a diplomáciai költségeket is megemelte. Ezt a költségnövekedést csak a gazdaságilag legfejlettebb államok tudták követni, a többség tehát a rendelkezésre álló források korlátozottsága miatt továbbra is csak a legfontosabb partnerekre koncentrált. A sürüség csökkenése emellett a felhasznált adatbázisok különböző adatgyüjtési technikáiból is ered. Míg az 1960-as adatok feltételrendszere tartalmazza a többszörös akkreditációkat, addig az 1960 utáni hálózatok csak a rezidens képviseleteket modellezik. Az 1960 utáni csökkenés tehát a multiakkreditációk hiányából is következik. Mintavételi eljárástól függetlenül megállapítható ugyanakkor, hogy az államok számának gyors növekedését a diplomáciai képviseletek számai nem tudták lekövetni, tehát a hálózatok tényleges mérete messze elmarad a lehetséges maximális mérettől.

\footnotetext{
${ }^{5}$ Sürüségi értékhatár: $0 \leq \mathrm{D} \leq 1$.
} 


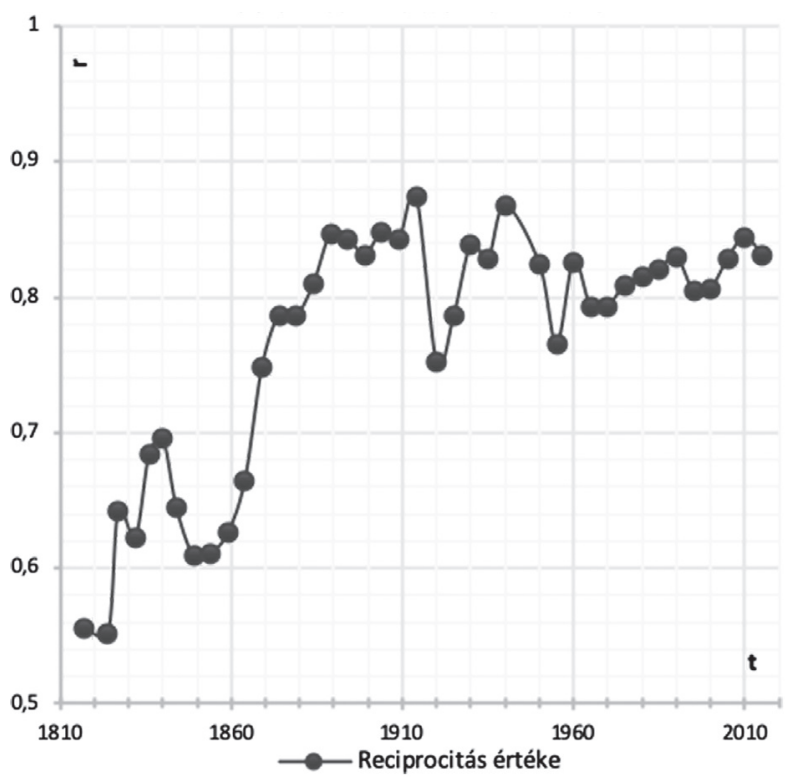

4. ábra. Reciprocitás (1817-2015)

A sürüség mért értékei természetesen összefüggésben vannak a hálózat részeinek összekapcsoltságával, azaz azzal ténnyel, hogy nem minden állam küld minden más államba diplomáciai képviseletet, illetve nem minden ország viszonozza a hozzá érkező missziókat, egyes kapcsolatok tehát aszimmetrikusak maradnak. Az elemzett hálózatok érdekessége azonban az, hogy a kapcsolatok jóval szimmetrikusabbak az átlagos ${ }^{6}$ irányított hálózatoknál, a vizsgált időszakban a reciprocitás $(r)$ átlagos értéke $r \approx 0,76$ volt. $^{7} \mathrm{~A} 4$. ábrát elemezve kitünik, hogy a diplomáciai kölcsönösség a 19. század második felében átlépte ezt az $r=0,7$ pontos küszöböt, ettől kezdődően mintavételi eljárástól függetlenül végig átlag felett maradt. A kisebb-nagyobb visszaeséseket áttekintve a szimmetrikusság kiterjedt háborúk, gazdasági válságok következtében (1920, 1935, 1950), illetve tömbök közötti ellenségeskedés (1955), továbbá a dekolonizációs folyamatok (1965) eredményeként átmenetileg csökkent. A diplomáciai képviseletek relatíve magas szimmetrikussága ugyanakkor az alacsony sürüségi adatokkal együtt értelmezendő. Ahogyan korábban láttuk, a hálózatokban részt vevő államok lehetséges kapcsolataik számának csak relatíve kevés hányadát használták ki, ezekre a megvalósuló kapcsolatokra vonatkoznak az imént ismertetett magas

${ }^{6}$ Példának okáért Mark Newman (2010) a World Wide Web irányított hálózatában mért $\mathrm{r} \approx 0,54$ értéket már „szokatlanul magasnak” minősítette.

${ }^{7}$ Reciprocitási értékhatár: $0 \leq \mathrm{r} \leq 1$. 
reciprocitási adatok. Az alacsony sürüségi adatokból azonban az is kiütközik, hogy a hálózatokban létrehozható kapcsolatok többsége nem alakul ki, a hálózati szimmetrikusság magas aránya tehát végső soron nemcsak a létrejövő kapcsolatokra, de a nem megvalósuló kapcsolatokra is igaz. Másként megfogalmazva, az elemzett hálózatokban a létező és a nem létező kapcsolatok többségében egyaránt szimmetrikusságot mutatnak: ha létrejött egy kapcsolat, akkor azt többségében viszonozták ${ }^{8}$, ha viszont nem, akkor az egyoldalú kezdeményezés jobbára elmaradt.

A hálózat alkotóelemeinek, sürüségének és szimmetrikusságának arányváltozásai természetesen hatást gyakoroltak a hálózatokban létrejövő kapcsolatok mennyiségére is. Utóbbiak közül az új alkotóelemek megjelenése rövid távon csökkentette a hálózatok sürüségét, ugyanakkor hosszú távon növelte a létrehozható kapcsolatok számát. Az újonnan belépők kapcsolatrendszerének folyamatos növekedését a kapcsolatok szimmetrikusságra való törekvése is felerősítette, amely - mintegy hálózati befolyásként - a létrejövő egyirányú kapcsolatok többségét idővel szimmetrikussá tette. Bár a hálózatba belépők nagy száma miatt a hálózatok sủrüsége soha nem lépte át a $\mathrm{D}=0,5$-ös értéket, azonban a fentebb részletezett folyamatok révén az alkotóelemek és a hálózatok fokszáma $(k)$

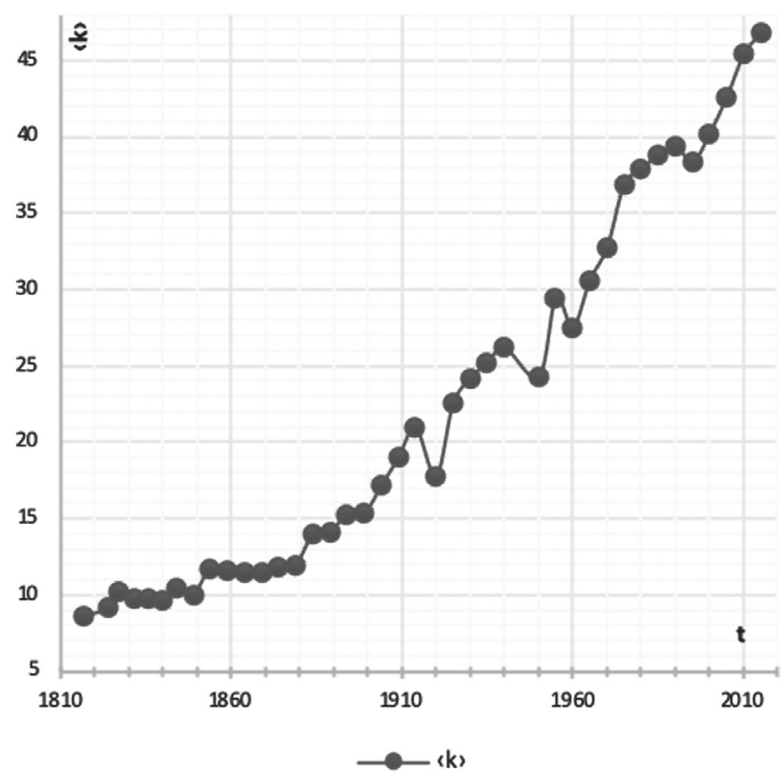

5. ábra. Átlagos fokszámeloszlás (1817-2015)

\footnotetext{
${ }^{8} \mathrm{Az}$ előzőekben felvázolt számadatok alapján a mintavételi időszakban a létrejövő kapcsolatok átlagosan 76\%-os eséllyel váltak szimmetrikussá.
} 
folyamatosan nőtt. Ehelyütt egyelöre csak az átlagos fokszámot vizsgálva (〈k〉) kijelenthető, hogy ez az érték 1817-1914 között 143,4\%-kal, 1914 és 2015 között pedig 123,4\%-kal növekedett (5. ábra). A fokszám mennyisége természetesen a hálózat különböző alkotóelemeit vizsgálva eltérő módon változott, kijelenthető ugyanakkor, hogy a középértéket a centrális szereplők rendkívül magas értéke jelentősen befolyásolta. Ennek mértéke az idő előrehaladtával folyamatosan nőtt: a legmagasabb fokszámmal rendelkező államok 1817-ben 22,4; 1914-ben 61,1; 1955-ben 121,6; 2015-ben pedig már 307,2 kapcsolattal haladták meg az átlagos fokszám értékét. A centrális és periferikus szereplők kapcsolatainak sürűsége között tehát jelentős eltérések mutatkoznak (Duque, 2017, 13.).

\section{CENTRÁLIS SZEREPLŐK}

Utóbbiból is jól kivehető, hogy a centrális szereplők hálózati befolyása a vizsgált periódus alatt fokozatosan növekedett. Ennek a folyamatnak a követésében a közeliség, a köztiség és a fokszámcentralitás értékeinek elemzése nyújthat segítséget, jelen tanulmány terjedelmi korlátok miatt ezek közül kizárólag utóbbira koncentrál. A fokszámcentralitás a központiság mérésének legkézenfekvőbb mérőszáma, amely az egyes pontok kapcsolati számát viszonyítja egyrészt más csúcspontok fokszámához, másrészt az összes kapcsolat mennyiségéhez (Barabási, 2016, 63.; Newman, 2010, 168-169.). Mivel az elemzett példák irányított hálózatok, ezért a bejövő $\left(k_{b e}\right)$ és kimenő $\left(k_{k i}\right)$ fokszámokat különválasztottuk, előbbi a fogadott külképviseleteket, utóbbi a küldött missziók számát jelöli. A bejövő fokszám tekintetében jól kirajzolódik, hogy az elemzett mintegy kétszáz év alatt pusztán négy ország került olyan előnyös helyzetbe, hogy a legmagasabb bejövő fokszámú pozíciót begyüjtse. A negyven mintavételi évben 47,5\%-ban Franciaország, 35\%-ban az USA, 2,5\%-ban az Egyesült Királyság, 15\%-ban pedig több ország (Franciaország, Egyesült Királyság, Németország, USA) együttesen osztozott az adott évre vonatkozó legmagasabb fogadott külképviseleti mennyiségen (6. ábra). Az adatokból szintén kitünik, hogy míg a francia vezető szerep a második és különösen az első világháború előtti időszakra volt jellemző, addig 1950 után az USA vált a diplomáciai külképviseletek legfontosabb célországává.

A legmagasabb bejövő fokszámmal rendelkező országok listája kiválóan tükrözi a hálózatelmélet presztízsről kialakított elképzeléseit, és igazolja, hogy a magas bejövő kapcsolatszámmal rendelkező csúcspontokhoz érkező kapcsolatok interakciós befektetésnek tekinthetők. A diplomácia világában ez a tulajdonság az úgynevezett szelekciós kényszerből következik, azaz abból a jellegzetességből, hogy az államok korlátozott anyagi erőforrásaikat kizárólag a számukra legelőnyösebb külképviseletek fenntartásába próbálják fektetni. Brandon J. Kinne 


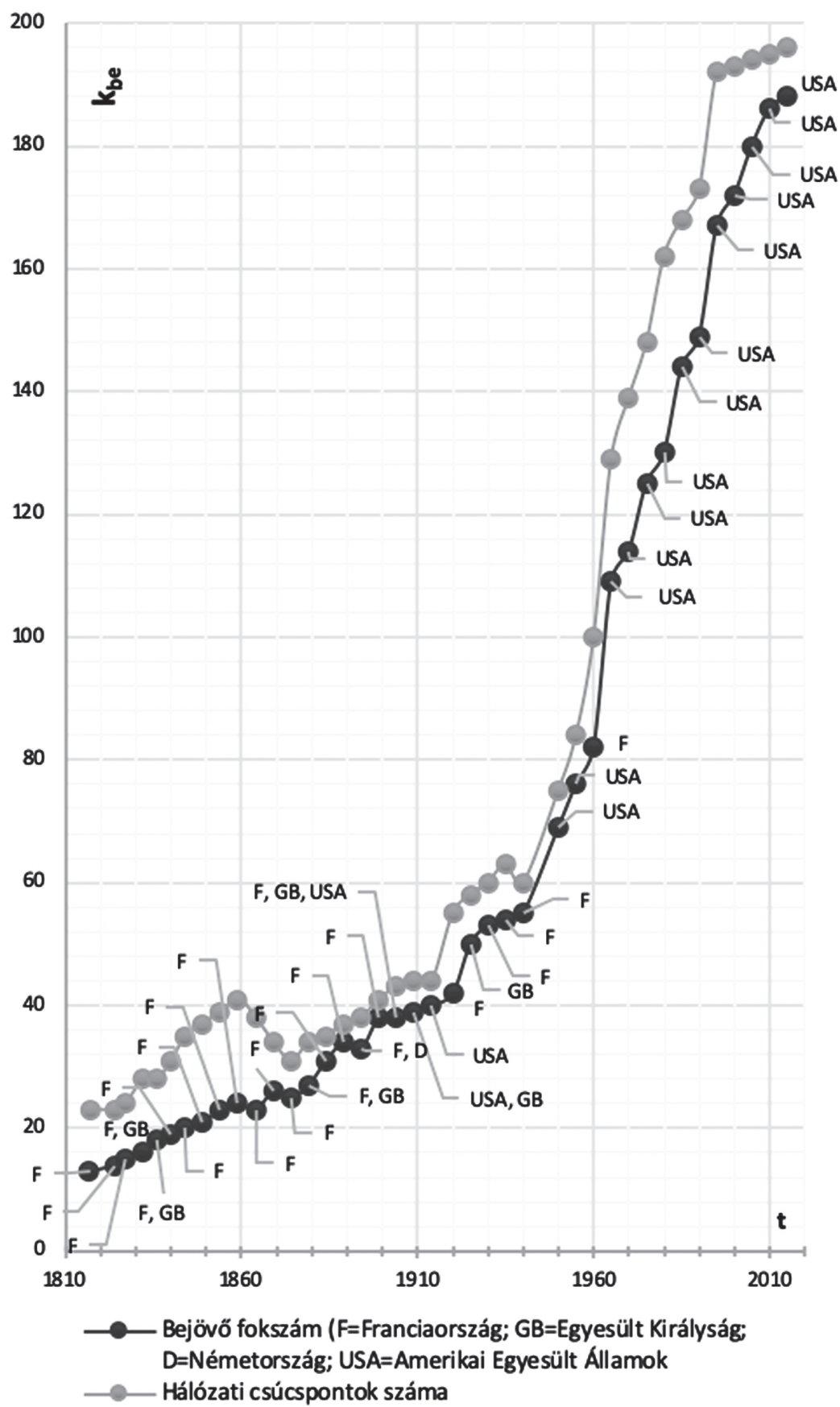

6. ábra. Legmagasabb bejövő fokszámmal rendelkező csúcspontok/államok (1817-2015) 
álláspontja szerint ez a szelekciós preferencia nem pusztán a diadikus/bilaterális párok viszonyrendszeréből következik: az újonnan létesített képviseletek a hálózati szerkezet révén is determináltak, mivel az államok diplomáciai kötelékeiket más országok kapcsolathálója alapján alakítják ki (Kinne, 2014, 247.). Ez a hálózati hatás egy diplomáciai képviselet létesítésekor érvényesül a költségminimalizálás és feladatmaximalizálás kapcsán, valamint a külügyi döntések közvetett külpolitikai jelzései révén. Másként megfogalmazva, a missziót létrehozó állam a bilaterális viszonyok mellett figyelembe veszi a kirendeltséget fogadó ország diplomáciai hálózatának összetételét is, s a képviselet hatásfokának maximalizálására, illetve a költségek minimalizálására törekedve ezután dönt saját külképviseleti szerkezetéről. Ebből következően a legmagasabb bejövő fokszámmal rendelkező országok a képviselet-létesítés szelekciós kényszere miatt a nemzetközi diplomáciai hierarchia csúcsán helyezkednek el, ők rendelkeznek a legtöbb diplomáciai hozzáféréssel, emiatt befolyásuk számottevő (Maliniak-Plouffe, 2011, 4-6.). Széles körü mozgásterüket jól mutatja, hogy a legmagasabb bejövő fokszámok az 1817-1864 és az 1965-1995 közötti időszakoktól eltekintve végig megközelítették az adott évre vonatkozó lehetséges maximumot, ugyanakkor azt ténylegesen soha nem érték el.

Bár a legmagasabb bejövő fokszámmal rendelkező országok presztízse és hálózati befolyása központi szerepet játszik a centralitás vizsgálatakor, azonban nem elhanyagolhatók azok az államok sem, amelyek a mért legmagasabb értékeket megközelítették. A kutatás ezen centrális szereplök kiválasztása érdekében öszszegyüjtötte azon államokat is, amelyek a mintavételi években bekerültek a tíz legmagasabb bejövő fokszámmal rendelkező ország közé (7. ábra). Annak ellenére, hogy a csoport szereplöinek bejövő fokszámai között jelentős eltérések mutatkoztak, a top 10-ek tagjai mind a diplomáciai tér olyan aktív és nagy befolyással bíró szereplőinek tekinthetők, akikre az államok többsége hasznot eredményező diplomáciai befektetésként tekintett. A csoport elemzésekor az egyik legszembetűnőbb jellegzetesség az abban részt vevők alacsony száma. A mintavételi időszakban összesen harminckét állam ${ }^{9}$ tudott bekerülni a mért évben legtöbb bejövő fokszámmal rendelkező tíz ország közé. Ezek közül a központi szereplők közül húsz állam tízszer vagy annál kevesebbszer került be a csoportba, Belgium, Németország, Olaszország, az USA, valamint Franciaország és az Egyesült Királyság viszont harmincnál is többször, utóbbi kettő pedig mind a negyven min-

\footnotetext{
${ }^{9}$ A kutatás az adatok összevetésének effektivitása érdekében egyes államok elnevezéseit a vizsgált időszak alatt nem változtatta, azaz egyes releváns esetekben a megszűnő államot és jogutódját kontinuitásként kezelte. Ilyen eset volt például Németország vagy Oroszország. Előbbi esetében a Német Birodalmat, a Weimari Köztársaságot vagy az NSZK-t egyaránt a Németország elnevezés jelöli, utóbbi esetében pedig az Oroszország megjelölés a cári időszakot és a Szovjetuniót egyaránt takarja. Az adatok megfeleltetése természetesen csak releváns esetekben volt lehetséges, példának okáért Ausztria-Magyarország a felbomlás után érthető okokból már külön államként szerepel.
} 


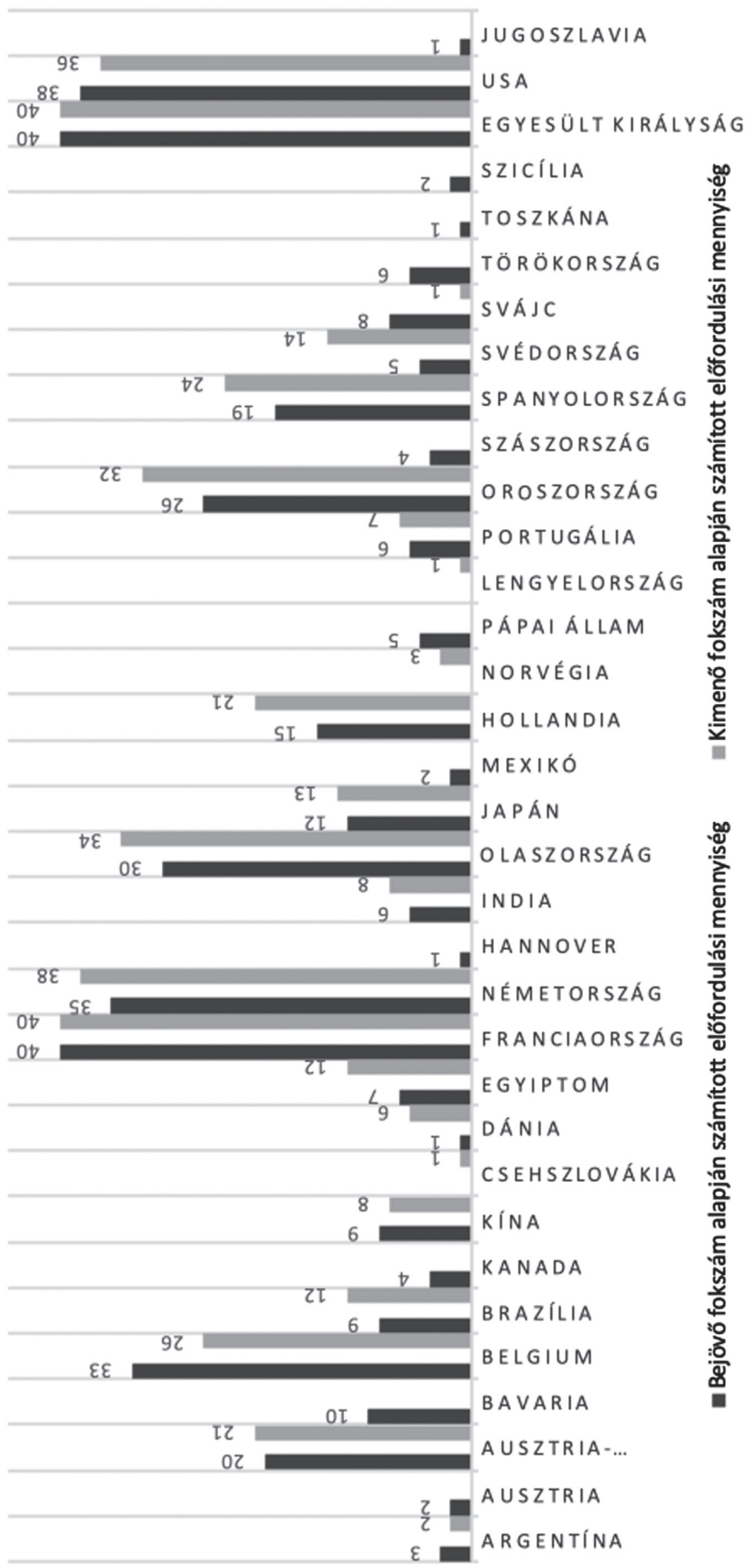

7. ábra. A 10 legmagasabb bejövő és kimenő fokszámmal rendelkező országok csoportja (1817-2015) 
tavételi alkalommal. Az imént említett hat ország központi szerepét jól jellemzi, hogy a teljes periódusban létrejövő 98347 bejövő kapcsolat 14,12\%-a ezekbe az országokba irányult. A mért időszakban legmagasabb diplomáciai presztízzsel rendelkezők tehát egy meglehetősen zárt csoportot alkottak, az abba való bekerülés és bent maradás során pedig nem pusztán a diplomáciai vonzerő számított, de az is, hogy az adott állam mióta volt tagja a nemzetközi rendszernek, abban milyen szerepet töltött be, illetve hogy külső és belső viszonyainak stabilitását meddig tudta megörizni.

Míg a bejövő fokszám az államok egymással szembeni megítélésére utal, addig a kimenő kapcsolatok az egyes országok diplomáciai befektetéseinek fokmérői. Mivel ez a mérőszám nem a hálózaton belüli alkotóelemek döntéseitől, hanem az individuális szereplők egyéni elhatározásától függ, ezért a legfontosabb államok összetétele a bejövő fokszámhoz képest valamelyest diverzifikáltabb képet mutat. Ez jól látszódik a legmagasabb kimenő fokszámmal rendelkezők összetételében, amelyben a mért időszak 32,5\%-ában több ország együttesen osztozott a legmagasabb kimenő fokszámon. Ebből következően az önállóan betöltött pozíciók aránya csökkent: az USA a negyven mintavételi év 25\%-ában, Franciaország 22,5\%ban, az Egyesült Királyság 12,5\%-ban, Oroszország, Ausztria-Magyarország és Olaszország pedig egyenként 2,5-2,5\%-ban tudta magáénak a legtöbb kimenő külképviseleti mennyiséget (8. ábra). A legmagasabb kimenő értékkel rendelkező pozíciók diverzifikáltsága az egyes történeti periódusokat vizsgálva is szembetűnő. Míg a legmagasabb bejövő fokszámú adatok esetében egyértelmü volt Franciaország 19. századi és az USA 20. századi vezető pozíciója, addig a kimenő fokszámcentralitás esetében a hosszabb távú egyoldalú elsőbbség csak 1990-től jellemző. Az USA vezető szerepének fokozatos előtérbe kerülését magyarázza az államok számának második világháború utáni drasztikus növekedése, amelynek hatására a diplomáciai költségek megnőttek, és csak a gazdaságilag legfejlettebb államok tudtak extenzív kapcsolathálózatot fenntartani. A kimenő kapcsolatok centrális szereplőinek maximális fokszámhoz viszonyított kimenő fokszáma a folyamat hatására csökkent, a maximális lehetséges kapcsolatok, valamint a megvalósuló linkek száma között egyre nagyobb eltérések mutatkoztak. A 8. ábrán megfigyelhető folyamatot utóbbiak mellett természetesen az adatgyüjtésből kivett multiakkreditációk hiánya is indukálja.

Szintén a nagyszámú külképviselet fenntartásával kapcsolatos költségekkel állhat összefüggésben, hogy a magas kimenő fokszámmal rendelkező centrális szereplők száma a bejövő fokszámnál tapasztalható arányoknál is alacsonyabb. A mintavételi időszakban huszonhárom ország került be a tíz legtöbb kimenő fokszámot összesítő diagramba (7. ábra), ezek összetétele pedig egyértelműen jelzi, hogy kiterjedt külképviseleti hálózatot csak gazdaságilag fejlett országok tarthattak fenn. Ezek közül a központi szereplök közül kilenc állam tízszer vagy annál kevesebbszer került be a csoportba, a középmezőnybe nyolc ország sorol- 


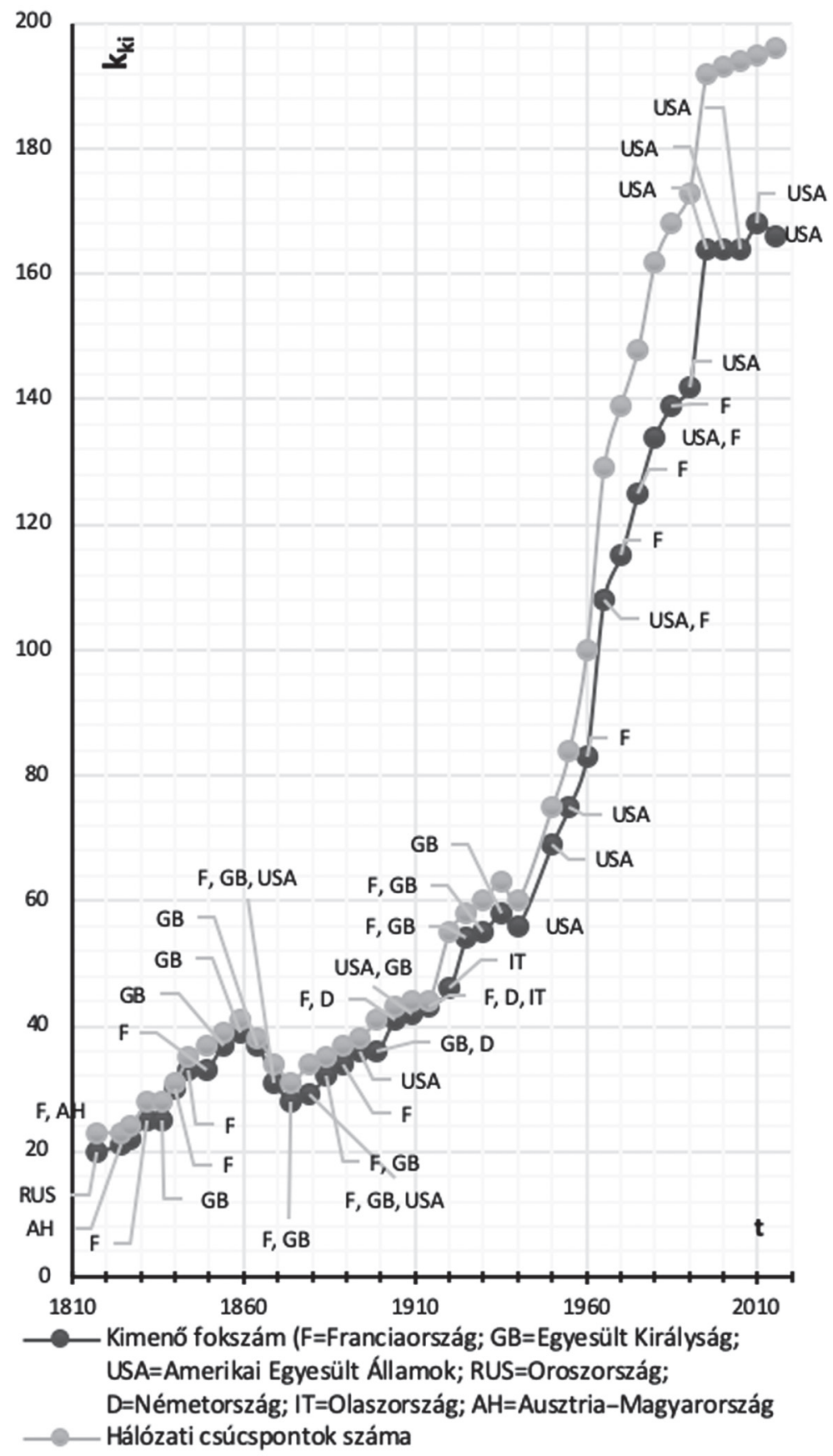

8. ábra. Legmagasabb kimenő fokszámmal rendelkező csúcspontok/államok (1817-2015) 
ható, egyenként tíz és harminc közötti előfordulással. A top 10-ek csoportjában legtovább jelen lévők száma ismételten hat: Németország, Olaszország, Oroszország, az USA, valamint Franciaország és az Egyesült Királyság harmincnál is többször került be a csoportba, utóbbi kettő ismételten mind a negyven mintavételi alkalommal. Belgium középmezőnybe történő visszaesése jelzi az ország bejövő és kimenő kapcsolatai között lévő számottevő különbséget, amit az országba delegált nemzetközi szervezetek generálnak, a bejövő kapcsolatok javára. Oroszország belépése a top 6-ok csoportjába szintén érthető fejlemény, ami jól reprezentálja az orosz külpolitika rezsimváltások során is fennmaradó alapvetéseit. A legmagasabb kimenő fokszámmal rendelkező centrális szereplők tehát a legfontosabb célországokhoz hasonlóan egy rendkívül zárt csoportot alkotnak. Erről a zártságról sokat elmond, hogy utoljára Kína volt képes új csatlakozóként belépni a top 10-ek csoportjába, ettől eltekintve a legfontosabb célországok csoportjának tagjai között 1975 óta, míg a legtöbb képviseletet küldő centrális szereplők között pedig 1985 óta nincs változás.

\section{KÖVETKEZTETÉSEK}

A tanulmány által ismertetett adatok a nemzetközi tanulmányok és a hálózatelméleti kutatások számára is kézzelfogható eredményeket produkáltak. A nemzetközi tanulmányok esetében a kutatás egyebek mellett bizonyította, hogy megfelelő adatgyüjtés esetén rendszerszintü összefüggések is modellezhetők, ezek a kapcsolatszerkezetek elemezhetők, a nemzetközi rendszer rétegzettségei, illetve a hatalom absztrakt jellegzetességei pedig kvantitatív módszerekkel kimutathatók. A kapott eredmények cáfolják a feltételezést mely szerint a digitális kapcsolattartás elterjedése miatt a külképviseleti érdekképviselet elvesztheti jelentőségét: a nagykövetségi posztok aránya 2000 és 2015 között - az államok számának 1,6\%-os növekedése mellett - kb. 19\%-kal növekedett, az utolsó mintavételi évben pedig már több mint kilencezer diplomáciai föképviselet működött a világon. Szintén számottevő trend, hogy az eredmények tanulsága szerint a diplomáciai kapcsolódások kialakulását nem pusztán bilaterális (vagy diadikus) viszonyok határozzák meg, a hálózati szerkezet önmagában is döntően befolyásolja a diplomáciai kapcsolatok formálódását, egyúttal az államok abban kifejtett effektivitását. Az elemzés szintén ráirányította a figyelmet arra, hogy a diplomáciai befektetés legfontosabb forrása a külképviselet-létesítés, amely a magas viszonzási hajlandóság miatt növeli a kezdeményező államok nemzetközi beágyazottságát: mivel a kimenő kapcsolatok nagy arányban eredményeznek bejövő kapcsolatokat, ezért az adott állam centralitása, presztízse és diplomáciai hatékonysága a befektetések révén növekszik. 
A nemzetközi tanulmányok tudományspecifikus következtetéseinek további listázása helyett érdemes rámutatni néhány olyan eredményre is, amelyek általános hálózatelméleti jelenségekre reflektálnak. Ezek közül az egyik legszembetűnőbb jelenség, hogy a diplomáciai kapcsolódásokat más valódi hálózatokhoz hasonlóan a növekedés jellemzi, ennek a növekedésnek a dinamikája azonban az utolsó mintavételi években fokozatosan lassult, amely természetesen hatást gyakorolt a topológiára és annak tulajdonságaira is. Ez a hálózatok transzformációját nézve azt jelentette, hogy a növekedés dinamikus időszakában egyes országok hosszabb távú hálózati jelenlétük és népszerüségük okán centrális szereplökké váltak, a megnövekedett szerep azonban sosem eredményezte óriás komponens vagy központosított (csillag formájú) topológia kialakulását. A hálózatokat inkább egy olyan decentralizált struktúra jellemzi, amelyben egyes csúcspontok központi pozíciója a növekedési időszak dinamikus periódusában növekedett, míg annak lassulása során a linkek számának fokozatos kiegyenlítődése révén csökkent. A topológia változása ugyanakkor sosem alakított ki elosztott hálózati szerkezetet, a népszerüségi és erőforrásbeli különbségek a mintavételi periódusban végig fenntartották a diplomáciai hálózatok hierarchikusságát. 


\section{MELLÉKLET}

Diplomáciai képviselek globális hálózatai Referenciahálózatok

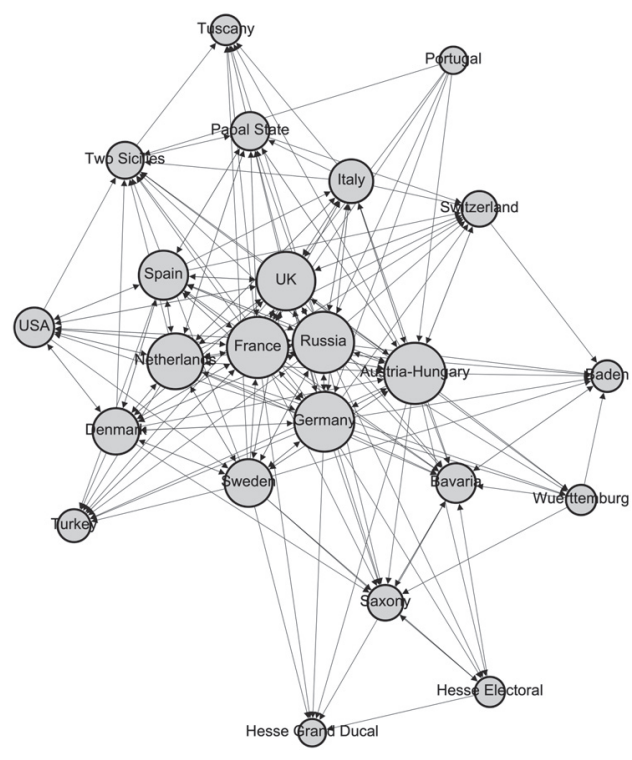

1817

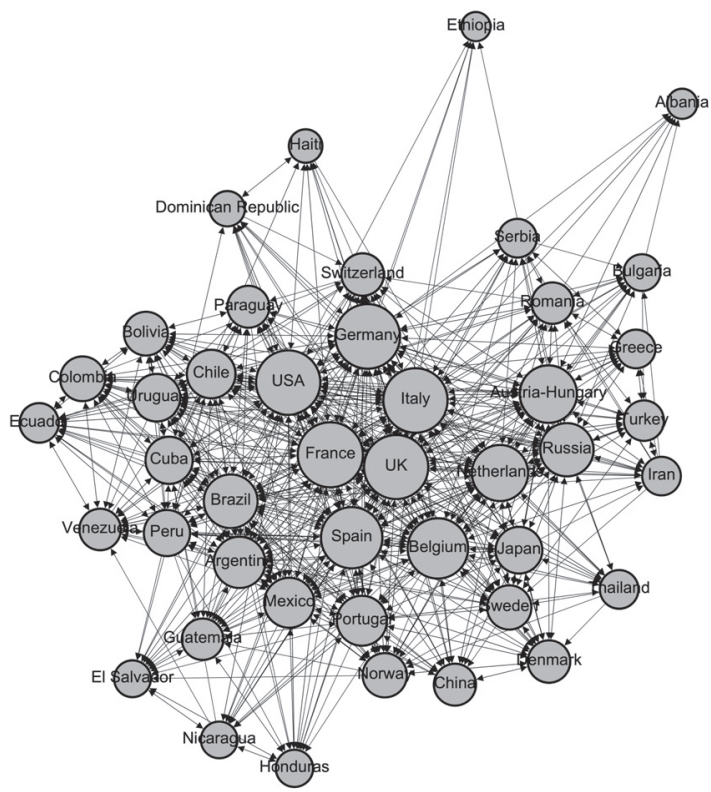

1914 


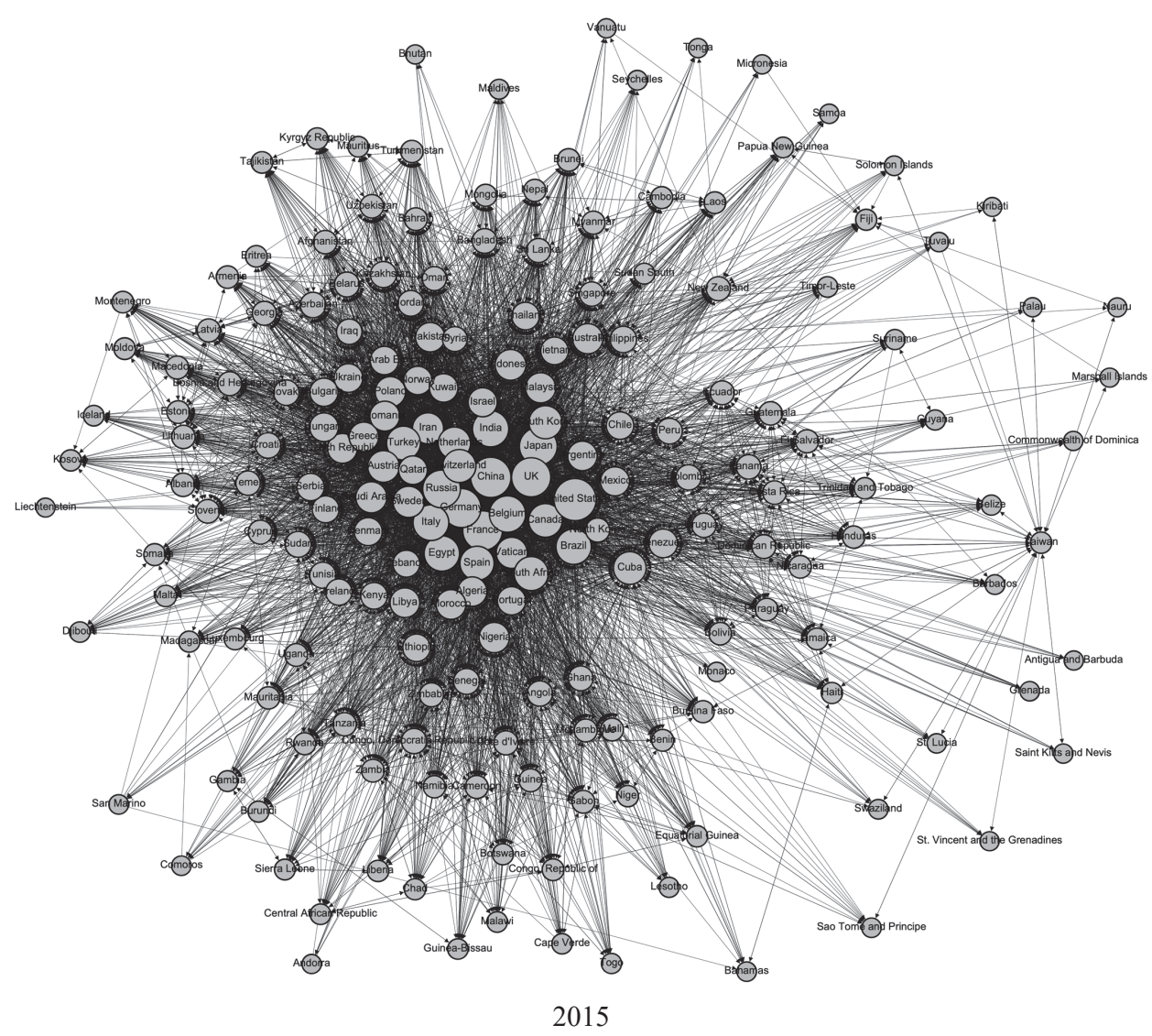

Saját szerkesztés (források: Bayer, 2006; Moyer et al., 2016; Europa Publications, 2016; szoftver: Gephi 0.9.2 201709242018)

A tanulmányhoz kapcsolódó kutatás a Nemzeti Tehetség Program támogatásával valósult meg. Pályázati azonosító: NTP-NFTÖ-18-B-0352

Projekt címe: A nemzetközi kapcsolatok hálózattudományi megközelítései 


\section{IRODALOM}

Barabási A.-L. (2016): A hálózatok tudománya. Budapest: Libri Könyvkiadó

Bastian, M. - Heymann, S. - Jacomy, M. (2009): Gephi: An Open Source Software for Exploring and Manipulating Networks. International AAAI Conference on Weblogs and Social Media.

Bayer, R. (2006): Diplomatic Exchange Dataset, v2006.1. http://correlatesofwar.org (letöltve: 2018. 09. 20.)

Duque, M. (2017): Core-Periphery Structure in the International Status Hierarchy. Belfer Center for Science and International Affairs, Harvard Kennedy School, 1-38. https://politicalscience. nd.edu/assets/236649/ (letöltve: 2019. 04. 29.)

Europa Publications (2016): The Europa World Year Book. 57 th edition. London: Routledge

Kinne, B. J. (2014): Dependent Diplomacy: Signaling, Strategy, and Prestige in the Diplomatic Network. International Studies Quarterly, 58, 247-259. DOI: 10.1111/isqu.12047

Maliniak, D. - Plouffe, M. (2011): A Network Approach to the Formation of Diplomatic Ties. WORKING DRAFT, San Diego: University of Chicago, 1-24.

Moyer, J. D. - Bohl, D. K. - Turner, S. (2016): Diplometrics: Diplomatic Representation. S. Frederick S. Pardee Center for International Futures. http://pardee.du.edu/diplometrics (letöltve: 2018. 09. 20.)

Neumayer, E. (2008): Distance, Power and Ideology: Diplomatic Representation in a World of Nation-states. Area, 40, 2, 228-236. DOI: https://doi.org/10.1111/j.1475-4762.2008.00804.x

Newman, M. E. J. (2010): Networks: An Introduction. New York: Oxford University Press DOI: 10.1093/acprof:oso/9780199206650.001.0001

Russett, B. M. - Lamb, C. W. (1969): Global Patterns of Diplomatic Exchange 1963-1964. Journal of Peace Research, 6, 1, 37-55. https://doi.org/10.1177/002234336900600104

Victor, J. N. - Montgomery, A. H. - Lubell, M. (eds.) (2017): The Oxford Handbook of Political Networks. Oxford: Oxford University Press. DOI: 10.1093/oxfordhb/9780190228217.001.0001

Westerwinter, O. (2017): Uncertainty, Network Change and Costly Signaling: How the Network of Diplomatic Visits Affects the Initiation of International Conflict. Department of Political Science, University of St. Gallen, 1-46. https://www.alexandria.unisg.ch/252634/ (letöltve: 2019. 04. 29.) 